\title{
Dolastatin 9
}

National Cancer Institute

\section{Source}

National Cancer Institute. Dolastatin 9. NCI Thesaurus. Code C1969.

A substance orig inally isolated from the marine mollusk Dolabella auricularia with potential neoplastic activity. Dolastatin 9 binds to tubulin and blocks microtubule assembly, thereby inhibiting mitosis. ( $\mathrm{NCIO4)}$ 